\title{
Spatiotemporal changes in Chinese land circulation between 2003 and 2013
}

\author{
WANG Yahui ${ }^{1,2}$, ${ }^{*}$ LI Xiubin $^{1,2}$, XIN Liangjie ${ }^{1}$, TAN Minghong ${ }^{1,3}$, JIANG Min ${ }^{1,2}$ \\ 1. Institute of Geographic Sciences and Natural Resources Research, CAS, Beijing 100101, China; \\ 2. University of Chinese Academy of Sciences, Beijing 100049, China; \\ 3. International College, University of Chinese Academy of Sciences, Beijing 100190, China
}

\begin{abstract}
Land circulation is an important measure that can be utilized to enable agricultural management at a moderate scale. It is therefore imperative to explore spatiotemporal changes in land circulation and the factors that drive these variations in order to maintain and increase the vitality of the land rental market. An initial analysis of spatiotemporal patterns in land circulation is presented in this study on the basis of data from 169,511 farm households between 2003 and 2013. The rural fixed observation point system advocated by the Chinese Ministry of Agriculture was utilized for this analysis, and Heckman two-stage models were developed and estimated in order to identify the drivers of regional differences in land circulation at the national scale and at the levels of different terrains. The results of this study show that the rate of land circulation in China rose from $15.09 \%$ to $25.1 \%$ over the course of the study period, an average rate of $0.8 \%$. More specifically, data show that the rate of land circulation in the south of China has been higher than in the north, that the average land rental payment was 4256.13 yuan per ha, and that $55.05 \%$ of households did not pay such a fee during the land circulation process. In contrast, the average rent obtained was 3648.45 yuan per ha nationally even though $52.63 \%$ of households did not obtain any payments from their tenants. The results show that land quality, geographic location, transaction costs, and household characteristics have significantly affected land circulation in different regions of China. Specifically, the marginal effects of land quality and geographic location were larger in the plain regions, while transaction cost was the key factor influencing land circulation in the hilly and mountainous regions. The signal identified in this study, rent-free land circulation, is indicative of a mismatch that has led to the marginalization of mountainous regions and higher transaction costs that have reduced the potential value of land resources. Thus, as the opportunity cost of farming continues to rise across China, the depreciation of land assets will become irreversible and the phenomenon of land abandonment will become increasingly prevalent in hilly and mountainous regions in the future. The transaction costs associated with the land rental market should be reduced to mitigate these effects by establishing land circulation intermediaries at the township level, and the critical issues of land abandonment and poverty reduction in hilly and mountainous regions should arouse more attention.
\end{abstract}

Received: 2017-09-10 Accepted: 2017-11-23

Foundation: National Natural Science Foundation of China, No.41571095, No.41271119

Author: Wang Yahui, PhD Candidate, specialized in land use change and agricultural economy.

E-mail: wangyhui.15b@igsnrr.ac.cn

*Corresponding author: Li Xiubin, Professor, E-mail: lixb@igsnrr.ac.cn 
Keywords: land circulation; rent-free; driving factors; Heckman two-stage model; China

\section{Introduction}

A series of implementation opinions related to structural reforms of supply side agriculture were issued by the Chinese Ministry of Agriculture in January 2017 with the core aim of increasing the incomes of farmers. However, shortcomings in land fragmentation and small-scale management have proved to be key constraints preventing improvements in agricultural labor productivity and sectoral transformation (Deininger et al., 2012; Xie and Lu, 2017). There is no doubt that land circulation is one important measure that can be evaluated in order to achieve more efficient agricultural operations at the moderate scale. Thus, a series of policies aimed at encouraging land circulation have been introduced in recent years by the central government. In 2014, a series of opinions regarding the development of moderate scale management through land circulation were proposed. Subsequently, in 2016, another publication from the central government highlighted that the need for local governments to actively encourage family farms, agricultural cooperatives, and other business entities in order to strengthen land circulation services and the scaled management of agriculture. It is clear that the Chinese central government has provided a great deal of support to encourage land circulation from the perspective of top-level design (Wang et al., 2017b).

However, as the opportunity costs of farming and the price of agricultural inputs have continued to rise, the net available profits from agricultural operations have continued to narrow leading to the emergence of extensive farmland operations and the phenomenon of land abandonment, especially after 2008 (Wang et al., 2009; Xin and Li, 2009; Zhao and Li, 2012; Zhang et al., 2014). This has meant that a large proportion of the Chinese rural labor force has migrated from the countryside to cities because of the higher non-agricultural wage. This process has led to the development of a land circulation market, one inevitable trend in rural development.

The issues surrounding land circulation in China have stimulated a great deal of research attention within both domestic and foreign academic communities. International research on this issue has mainly focused on the efficiency of land circulation and the development of a land rental market since the end of the 20th century (e.g., Teklu and Lemi, 2004; Jin and Jayne, 2013; Shao et al., 2016). In poorly-developed regions such as Asia, Africa, and Latin America, more attention has been paid to the development of land circulation and its impacts on income growth and poverty reduction (Benjamin and Brandt, 2002; Deininger and Jin, 2008; Deininger et al., 2008; Jin and Jayne, 2013; Huy et al., 2016). In one recent study, Huy et al. (2016) noted that land circulation has improved the efficiency of land use and promoted fairness among farm households in Vietnam, building on the earlier work of Deininger et al. (2008) who showed that this process enhances the incomes of farmers and thus contributes to poverty reduction. Other studies have focused on land privatization and market transactions in Eastern Europe (Vranken and Swinnen, 2006), while in China, some early research emphasized an understanding of the factors driving land circulation. In this context, research has shown that land system defects, urbanization, and higher agricultural operating costs have been the main drivers of land circulation (Hu, 1997; Wang et al., 2016; Sun and Yang, 2017), while aging of the agricultural labor force, inefficiencies in the rental market, and the high costs of transactions have been the key issues underlying the lack of 
vitality in Chinese land circulation (Latruffe and Piet, 2014; Li and Dai, 2014; Huy et al., 2016; Wang et al., 2017a). It is also noteworthy that some scholars have also identified a large proportion of rent-free land circulation amongst households via large-scale field investigations (Wang et al., 2015).

As the phenomenon of land circulation has continued to expand across China, spatial differences have attracted an increased level of attention. To date, however, the vast majority of studies in this area have focused on isolated case studies, such as Chongqing Municipality, the Three Gorges Reservoir Area, and Jiangsu Province, and have emphasized the use of cross-sectional data; previous work has therefore encompassed limited time spans and sample size. Earlier work has, therefore, been unable to reveal spatiotemporal patterns in land circulation at large scales, especially nationwide (Du and Ou, 2008; Wang et al., 2015). Thus, to accurately analyze spatiotemporal changes in land circulation across China, it is necessary to first track farm households by utilizing large scale surveys that cover long time spans and incorporate regional heterogeneities. The rural fixed observation point system that was initiated and applied by the Chinese Ministry of Agriculture can be utilized in this context, it has included a long-term follow-up survey since 1986 and has annually captured data from 23,000 farm households in 360 villages distributed across 31 provincial-level areas within China. These data provide support to research projects on land circulation as they enable the identification of spatiotemporal trends and associated driving factors.

The objectives of this study are to: (1) Elucidate spatiotemporal patterns and trends in land circulation over the study period, and; (2) Identify the drivers of regional differences in land circulation by using Heckman two-stage models. The results of this study provide insights regarding the current land circulation situation in China and enable the identification of potential problems so that corresponding policy recommendations can be presented to improve the vitality of land use across the country.

\section{Data}

The data used in this study are derived from the rural fixed observation point system, which is managed by the Chinese Ministry of Agriculture (http://www.rcre.agri.cn/). This system was approved and established by the Central Secretariat in 1984, is organized by the central policy research office of the Ministry of Agriculture, and is managed by its rural economic research center. This survey was initiated in 1986 and continually tracked farm households until 2013. The resultant database has two distinct advantages: in the first place, the number of strongly represented samples is larger than that of any other institutional survey carried out in China, encompassing approximately 23,000 farm households in 360 villages across 31 provinces of China (Figure 1). Secondly, this database also includes a series of village and household questionnaires that contain a large amount of information about local economies, populations, the labor force, fixed assets, agricultural production, and social development. At the same time, household questionnaires include information about family demography, land use, geographic location, household assets, agricultural operations, and family incomes and expenditure. This database therefore provides a relatively comprehensive reflection of national land circulation at the micro scale.

It is important to note that the data used in this study just encompass the period between 2003 and 2013 and key indicators are missing for the period between 1986 and 2002. This 


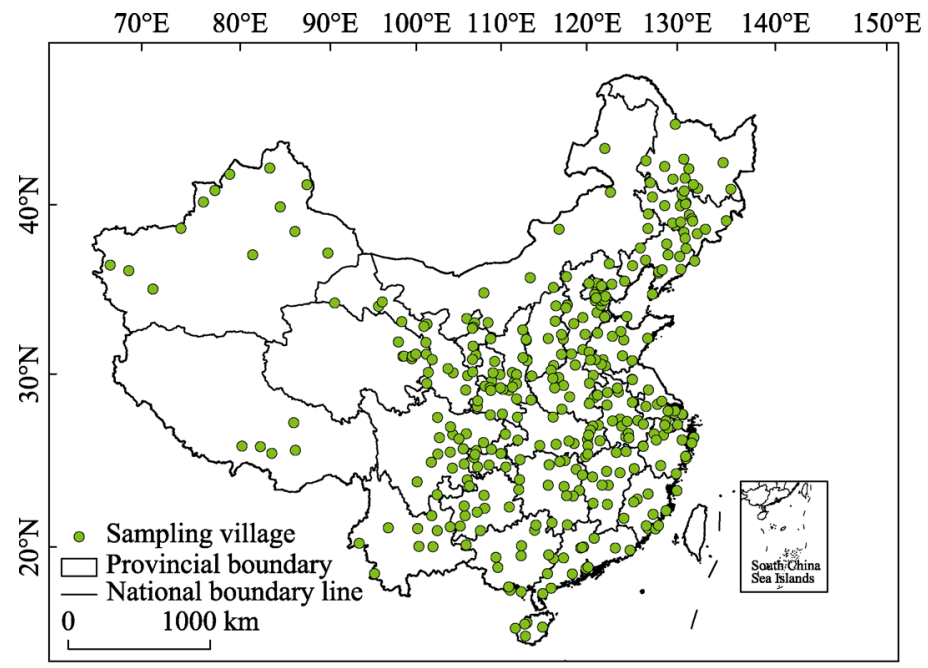

Figure 1 Distribution of Chinese villages investigated in this study

dataset therefore includes a total of 223,189 farm households surveyed from 360 villages distributed in 31 provinces across China; 194,603 of these households were also matched with village questionnaires. In order to reduce the number of statistical errors from missing indicators, a series of operations were applied to clean the data. Thus, 451 farm households that lacked provincial codes were eliminated to prevent sampling issues and 8140 households where the labor force number was greater than the total population were also eliminated. Finally, 16,136 households that lacked important indicators, such as crop planting area and land circulation, were also eliminated from the dataset to leave a total of 169,511 (Table 1). The effective sample proportion in the dataset was therefore $87.11 \%$.

Taking into account the high proportion of invalid samples, it was further necessary to test whether, or not, a farm household was randomly surveyed over two consecutive years; if this random sampling condition was not satisfied, then sample selection bias was present during data processing. Fortunately, the results of this test revealed sample randomness of sample loss for all sets of two consecutive periods; thus, the probability that any samples had been investigated over two consecutive years was $96.2 \%$ and therefore no selective bias occurred in sample processing. Table 1 summarizes the total number of farm households surveyed and involved in land circulation over the study period; these data show that the number participating in land circulation has tended to increase, especially after 2008.

Table 1 The effective number of farm households surveyed each year

\begin{tabular}{cccc}
\hline Year & $\begin{array}{c}\text { Total number } \\
\text { surveyed }\end{array}$ & $\begin{array}{c}\text { Renting-in } \\
\text { land }\end{array}$ & $\begin{array}{c}\text { Renting-out } \\
\text { land }\end{array}$ \\
\hline 2003 & 16,905 & 1231 & 1637 \\
2004 & 16,668 & 1233 & 1324 \\
2005 & 17,331 & 1126 & 1402 \\
2006 & 16,871 & 1126 & 1639 \\
2007 & 14,356 & 1211 & 1384 \\
2008 & 15,378 & 1033 & 1764 \\
2009 & 15,399 & 1132 & 1823 \\
2010 & 15,392 & 1509 & 2104 \\
2011 & 13,432 & 1641 & 1905 \\
2012 & 14,127 & 1838 & 2231 \\
2013 & 13,652 & 2050 & 2184 \\
Total & 169,511 & 15,130 & 19,397 \\
\hline
\end{tabular}

Data sourced from the rural fixed observation point system between 2003 and 2013. 


\section{Methods}

\subsection{Land circulation rate}

In order to comprehensively evaluate the current land circulation situation in China, three indicators were selected for use in this study based on earlier work (Luo et al., 2010). There are the total land circulation rate $(R T L C)$, the rented-in land area rate (RRILA), and the rented-out land area rate $(R R O L A)$.

(1) RRILA

The formula used to estimate the RRILA is as follows:

$$
R_{i t}^{i n}=\frac{N_{i t}^{i n}}{N_{i t}^{T}} \times 100 \%
$$

where $R_{i t}{ }^{i n}$ denotes the rented-in land area rate for $i$ province in $t$ year, while $N_{i t}{ }^{\text {in }}$ denotes the rented-in land area of $i$ province in $t$ year, and $N_{i t}{ }^{T}$ denotes the total land area of all surveyed households in $i$ province in $t$ year.

(2) RROLA

The formula used to estimate the RROLA is as follows:

$$
R_{i t}^{\text {out }}=\frac{N_{i t}^{\text {out }}}{N_{i t}^{T}} \times 100 \%
$$

where $R_{i t}{ }^{\text {out }}$ denotes the rented-out land area rate for $i$ province in $t$ year, while $N_{i t}{ }^{\text {out }}$ denotes the rented-out land area of $i$ province in $t$ year, and $N_{i t}{ }^{T}$ denotes the total area of all surveyed households in $i$ province in $t$ year.

(3) $R T L C$

The formula used to estimate $R T L C$ is as follows:

$$
R_{i t}^{T}=\frac{N_{i t}^{i n}+N_{i t}^{\text {out }}}{N_{i t}^{T}} \times 100 \%
$$

where $R_{i t}^{T}$ denotes the total land circulation rate for $i$ province in $t$ year, while $N_{i t}^{\text {in }}, N_{i t}^{\text {out }}$, and $N_{i t}{ }^{T}$ are the same as in equations (1) and (2), above.

\subsection{Land rent}

In order to facilitate comparisons of land rent between years and regions, a discount factor was applied to convert all values to one equivalent to 2013 , as follows:

$$
N P V_{2013}=N P V_{t} \times(1+i)^{2013-t}
$$

In this expression, $N P V_{2013}$ denotes land rent for 2013, while $N P V_{t}$ denotes land rent in year $t$ where $t$ is earlier than 2013, and $i$ denotes the discount rate set as equivalent to the national bank deposit rate for that year.

\subsection{Drivers underlying spatiotemporal differences in land circulation}

Data show that when farm households rented-in new land, this was not just from their counterparts or from the collectives of other villages, but also included reclamation. These varied sources are sometimes difficult to separate and thus calculate rent. In contrast, the land renting-out situation is simple and rents are simple to calculate. Thus, for these reasons, only farm households that rented-out land were considered as samples in this study to analyze the 
drivers of spatiotemporal differences in and circulation.

According to the theory of farmers' behavior (Low, 1986; Wang et al., 2017a), a household decision whether, or not, to rent out land, as well as its size, are not random but are rather the result of self-selection influenced by a series of factors, including household characteristics, economic level, and geographic location. As discussed above, a large amount of rent-free land circulation also occurs within China; thus, land circulation was divided into two stages in this study. The first stage model takes into account whether, or not, a farm household rents out land, denoted as a probability, while the second stage considers whether, or not, land rent is obtained, denoted as a numerical value. Although the Heckman two-stage model is presently used in this context to address the self-selection problem (Heckman, 1979), the sample size of this study is large enough to satisfy the normal distribution for the Probit model in the first stage; similarly, the error term of the Heckman two-stage model also satisfies the assumption of normal distribution (Certo et al., 2016).

In the first stage model applied in this study, the dependent variable was set to whether, or not, a farm household rented-out land (renting-out land $=1$, otherwise $=0$ ). A Probit model was therefore developed and estimated to identify the drivers underlying spatiotemporal differences in land circulation, as follows:

$$
\ln \left(\frac{P_{i t}}{1-P_{i t}}\right)=\mu_{i}+\sum_{j=1}^{m} \alpha_{j} X 1_{i t}
$$

In the second stage of the model applied in this study, the dependent variable was set as the size of land rent. We therefore utilized selected samples to identify the drivers of this variable via a regression equation, as follows:

$$
y_{i t}=\varepsilon_{i}+k \lambda_{i}+\sum_{j=1}^{m} \beta_{j} X 2_{i t}
$$

In equations (5) and (6), $P_{i t}$ denotes the probability that a farm household $i$ in year $t$ rented-out farmland, while $X 1_{i t}$ denotes a series of observable factors that affect whether, or not, renting our could occur, $\mu_{i}$ is the error term of the probability equation which conforms to a normal distribution with zero mean, $y_{i t}$ denotes the land rent per hectare (ha) received by a farm household $i$ in year $t, X 2_{i t}$ denotes a series of observable factors that affect the size of the land rent, $\lambda_{i}$ is the Inverse Mills Ratio (IMR), $\varepsilon_{i}$ is the error term of the regression equation which also conforms to a normal distribution with zero mean, $i$ and $t$ denote the farm household and year, respectively, and $m$ denotes the number of variables that affect land circulation. $\alpha_{j}$ and $\beta_{j}$ are the parameters to be estimated.

Thus, in order to obtain a value for $\lambda_{i}$ in this regression equation, probability equation (5) should first be estimated using a Probit regression of all samples. This step enabled us to estimate values of the unknown parameter vector for $\alpha$ and $\sigma$, while $\lambda$ was then estimated using the IMR formula incorporated into regression equation (6) as a new variable. We calculated $\lambda$ using the following equation:

$$
\lambda_{i}=\frac{\psi\left(-\alpha \cdot \frac{X 1_{i t}}{\sigma}\right)}{\phi\left(-\alpha \cdot \frac{X 1_{i t}}{\sigma}\right)}
$$

where $\Psi(\cdot)$ denotes the density function of the standard normal distribution, while $\phi(\cdot)$ denotes the probability distribution function of the standard normal distribution, $\alpha$ denotes the 
regression coefficient set for the independent variables in the probability equation, and $\sigma$ is the standard deviation (S.D) of the error term $\left(\mu_{i}\right)$ in the probability equation.

The Heckman two-stage model can be used to solve the self-selection problem by adding $\lambda$ to the regression; if $\lambda$ is not equal to zero, then there is a self-selection problem. In addition, since the correlation coefficient between the probability and regression equations is not significantly equal to zero, the two equations are related. In general, as ordinary least squares estimation leads to biased coefficients, the Heckman two-stage model is often used instead; this model was applied in this study in order to improve estimation precision and to accurately reveal the drivers underlying spatiotemporal variations in land circulation.

\subsection{Variables and statistical descriptions}

\subsubsection{Dependent variable}

As discussed above, the dependent variable in the first analytical stage was whether, or not, a farm household rents out land (i.e., if yes, the dependent variable equals to one, otherwise it equals to zero), while in the second stage, this variable was the land rent obtained. Detailed definitions of these variables are presented in Table 2.

\subsubsection{Independent variables}

On the basis of previous theoretical analyses and existing literature (Huy et al., 2016; Wang et al., 2017a), land quality, geographic location, transaction cost, and village and household characteristics were selected as independent variables in this study in an attempt to accurately identify the factors that drives spatiotemporal differences in land circulation. Applying the approach proposed by Latruffe and Piet (2014), the number of land parcels, and whether or not, a land circulation intermediary were used as proxy variables to measure the size of a transaction cost (Huy et al., 2016). In general, more household plots also mean a higher number of land disputes (Latruffe and Piet, 2014), although land circulation intermediaries can effectively reduce transaction costs via information searches, deal-making negotiations, and solving disputes (Huy et al., 2016). Statistical descriptions of variables are also presented as part of this research (Table 2) in order to better understand the change tendencies at the beginning and end of the study period.

\section{Results and discussion}

\subsection{Spatiotemporal changes in land circulation}

The data presented in Figure 2 show that the rate of land circulation in China rose from $15.09 \%$ in 2003 to $25.1 \%$ in 2013 , an average growth rate of $0.8 \%$. In terms of direction of change, the rate of land renting-in increased from $7.41 \%$ in 2003 to $8.1 \%$ in 2013 , a slight upward trend, while the rate of land renting-out rose from $7.68 \%$ in 2003 to $17 \%$ in 2013 , an increase of nearly $10 \%$ and a significant upward trend. It is also noteworthy that the national rate of land renting-out was about twice that of land renting-in in 2013, which illustrates that the extent of land management has gradually expanded in recent years.

The data presented in Figure 3 reveal the spatiotemporal characteristics of land circulation at the provincial level across China between 2003 and 2013. These values show that the overall rate of Chinese land circulation is 'higher in the south and lower in the north, as well as 
Table 2 Definitions and statistical descriptions of the variables used in this study

\begin{tabular}{|c|c|c|c|c|c|}
\hline \multirow{2}{*}{ Variables } & \multirow{2}{*}{ Definitions } & \multicolumn{2}{|c|}{2003} & \multicolumn{2}{|c|}{2013} \\
\hline & & Mean & S.D & Mean & S.D \\
\hline \multicolumn{6}{|l|}{ Dependent variable } \\
\hline $\begin{array}{l}\text { First stage model: } \\
\text { Land rented-out }\end{array}$ & Yes $=1$, otherwise $=0$ & 0.12 & 0.24 & 0.17 & 0.25 \\
\hline $\begin{array}{l}\text { Second stage model: Rent } \\
\text { per unit area }\end{array}$ & Rent obtained (yuan/ha) & 1792.5 & 6565.8 & 4097.4 & 8600.3 \\
\hline \multicolumn{6}{|l|}{ Independent variables } \\
\hline Land quality & $\begin{array}{l}\text { Yield per ha larger than the average in } \\
\text { village }=1 \text {, otherwise }=0\end{array}$ & 0.51 & 0.67 & 0.57 & 0.71 \\
\hline \multicolumn{6}{|l|}{ Geographic location } \\
\hline Suburban region & Located in the suburbs (yes $=1$, otherwise $=0$ ) & 0.16 & 0.36 & 0.16 & 0.37 \\
\hline Economic level & $\begin{array}{l}\text { Lowest level }=1, \text { medium level }=3 \text {, } \\
\text { highest level }=5\end{array}$ & 2.81 & 0.88 & 2.82 & 0.87 \\
\hline \multicolumn{6}{|l|}{ Transaction costs } \\
\hline Number of land parcels & Number of the plots in cultivation (plots) & 4.47 & 4.98 & 4.11 & 4.92 \\
\hline $\begin{array}{l}\text { Land circulation } \\
\text { intermediary }\end{array}$ & $\begin{array}{l}\text { Circulating intermediary in town (yes = } \\
1 \text {, otherwise }=0 \text { ) }\end{array}$ & 0.11 & 0.33 & 0.18 & 0.43 \\
\hline \multicolumn{6}{|l|}{ Household characteristics } \\
\hline $\begin{array}{l}\text { Rate of non-agricultural in- } \\
\text { come }\end{array}$ & $\begin{array}{l}\text { Rate of non-agricultural income in } \\
\text { household income }(\%)\end{array}$ & 58.21 & 38.29 & 76.98 & 42.22 \\
\hline Age of family head & Age of the household head (years) & 50.12 & 10.87 & 52.46 & 9.25 \\
\hline $\begin{array}{l}\text { Physical condition of fam- } \\
\text { ily head }\end{array}$ & $\begin{array}{l}\text { No ability to work }=1 \text {, average level }=3 \text {, } \\
\text { favorable level }=5\end{array}$ & 4.33 & 2.21 & 4.20 & 1.90 \\
\hline Number of labor force & $\begin{array}{l}\text { Number of people in the labors from } 16 \\
\text { years old to } 65 \text { years old }\end{array}$ & 2.17 & 1.02 & 2.22 & 1.08 \\
\hline Occupation & Agriculture $=1$, otherwise $=0$ & 0.88 & 0.31 & 0.86 & 0.32 \\
\hline Total value of productive assets & Total value of productive assets (yuan) & 5913.7 & 2819.1 & 9007.3 & 3285.2 \\
\hline \multicolumn{6}{|l|}{ Village characteristics } \\
\hline Per capita income in village & $\begin{array}{l}\text { Total income divided by total population } \\
\text { in village (yuan/year) }\end{array}$ & 2719.3 & 2799.2 & 4789.3 & 4319.8 \\
\hline Number of enterprises in village & Number of non-agricultural enterprises & 3.27 & 2.19 & 5.83 & 2.24 \\
\hline Rate of population outflow & $\begin{array}{l}\text { Outflow population number divided by } \\
\text { total people }(\%)\end{array}$ & 21.00 & 18.00 & 33.12 & 19.00 \\
\hline Financial constraints & Has get a loan $($ yes $=1$, otherwise $=0)$ & 0.05 & 0.21 & 0.09 & 0.29 \\
\hline
\end{tabular}

The data in this table are derived from computations based on rural fixed observation point data for 2003 and 2013.

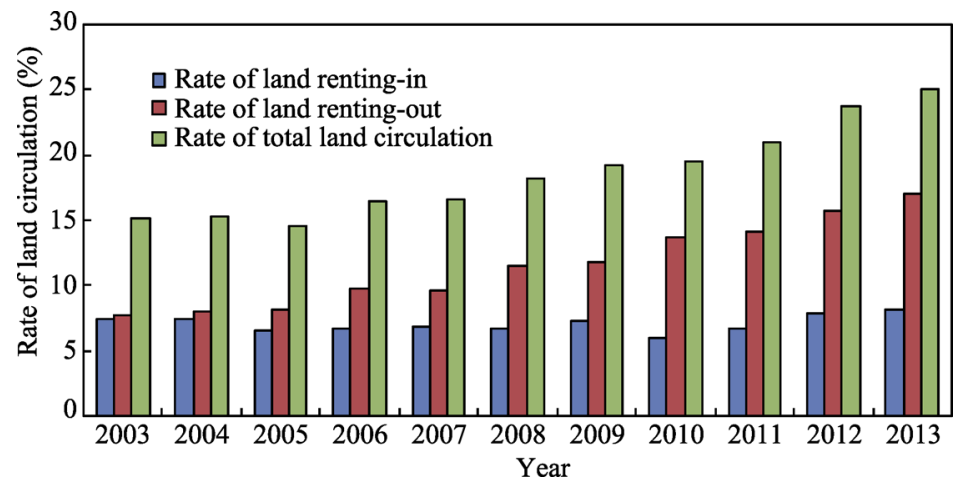

Figure 2 Land circulation rates in China between 2003 and 2013 

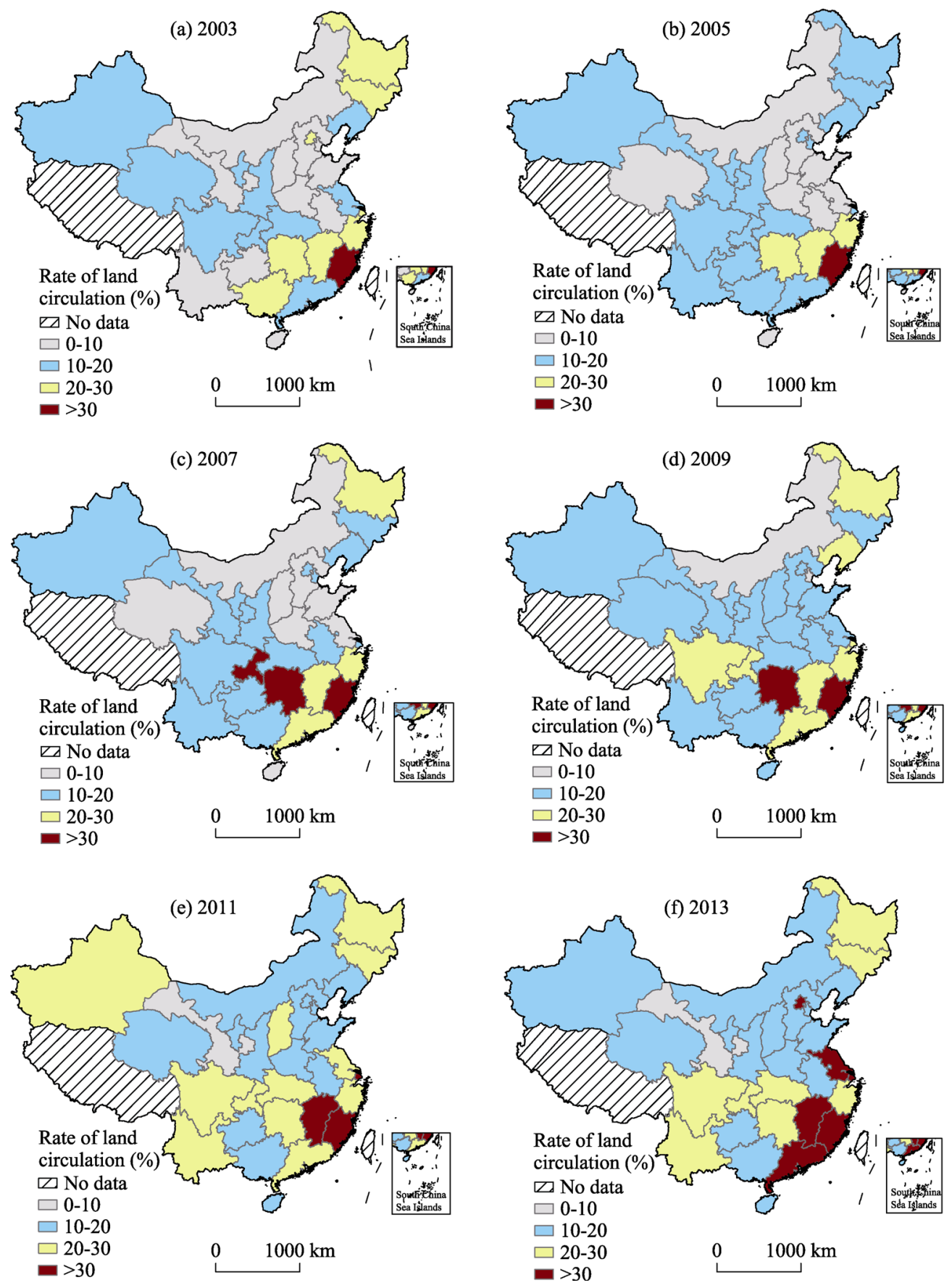

Figure 3 Patterns in land circulation at the provincial level across China between 2003 and 2013

(As no farm households were surveyed in Tibet in 2005, 2006, 2010, and 2013, land circulation rates for this region were not calculated because of sample size limitations.)

higher in the east and lower in the west'. The rates of land circulation in Inner Mongolia, Shaanxi Province, and in other western regions were often less than $10 \%$, for example, while the rates in Fujian, Zhejiang, and Guangdong provinces and other southeastern regions were more than $20 \%$, and sometimes higher than $30 \%$. In 2009, however, the land circulation rate 
was more than $10 \%$ in the vast majority of Chinese regions, with the exception of Inner Mongolia where the rate was just $8.28 \%$.

Data show that in 2013 the land circulation rate was less than $10 \%$ in just Gansu Province, while in some regions (e.g., Fujian, Zhejiang and Guangdong provinces as well as Beijing), rates of $70 \%$ or more were recorded.

Previous work has shown that the development of spatiotemporal differences in land circulation can result from various factors, including economic development, mechanization, non-agricultural activities, and income (Wang et al., 2017). It is clear that the rate of land circulation in China between 2003 and 2013 has risen; about 25\% of total farmland nationally is now characterized by separation of land contract and management rights.

\subsection{Spatial differences in land rent}

\subsubsection{The cost of renting-in land}

The data in Table 3 reveal regional differences in the cost of renting-in land. Although national land rent was about 4256.13 yuan per ha, 6169 farm households (ca. 55.05\% of the total surveyed) did not pay any rent. In other words, the rate of circulating land not generating rent reached as high as $55.05 \%$ during the study period, while in cases where land rents were paid, about $30 \%$ of farm households expended up to 7500 yuan per ha, while $7.81 \%$ paid more than 15,000 yuan per ha. The rates of land circulation without rent in the plain, hilly, and mountainous regions of China were $50 \%, 51.68 \%$, and $68.67 \%$, respectively; it is undeniable that a large amount of land circulation without rent occurs among smallholders in different regions.

Table 3 Regional differences in the cost of renting-in land

\begin{tabular}{|c|c|c|c|c|c|c|c|c|}
\hline \multirow{2}{*}{ Region } & \multicolumn{2}{|c|}{ No land rent } & \multicolumn{2}{|c|}{$\begin{array}{c}\text { Land rent } \\
(\leqslant 7500 \text { yuan } / \text { ha })\end{array}$} & \multicolumn{2}{|c|}{$\begin{array}{l}\text { Land rent }(7500- \\
15,000 \text { yuan/ha) }\end{array}$} & \multicolumn{2}{|c|}{$\begin{array}{c}\text { Land rent } \\
(\geqslant 15,000 \text { yuan/ha })\end{array}$} \\
\hline & $\begin{array}{l}\text { Number of } \\
\text { households }\end{array}$ & $\begin{array}{l}\text { Rate } \\
(\%)\end{array}$ & $\begin{array}{l}\text { Number of } \\
\text { households }\end{array}$ & $\begin{array}{l}\text { Rate } \\
(\%)\end{array}$ & $\begin{array}{l}\text { Number of } \\
\text { households }\end{array}$ & $\begin{array}{l}\text { Rate } \\
(\%)\end{array}$ & $\begin{array}{l}\text { Number of } \\
\text { households }\end{array}$ & $\begin{array}{l}\text { Rate } \\
(\%)\end{array}$ \\
\hline Total samples & 6169 & 55.05 & 3546 & 31.64 & 590 & 5.26 & 875 & 7.81 \\
\hline Plain & 1579 & 50.33 & 1157 & 36.89 & 133 & 18.81 & 268 & 8.54 \\
\hline Hilly & 2613 & 51.68 & 1851 & 36.61 & 304 & 6.01 & 288 & 4.51 \\
\hline Mountainous & 1977 & 68.67 & 494 & 17.16 & 172 & 5.97 & 236 & 8.19 \\
\hline
\end{tabular}

The data in this table are derived from computations based on rural fixed observation point data.

\subsubsection{The cost of renting-out land}

The data in Table 4 reveal regional differences in the cost of renting-out land. Although the national average land rent obtained over the period of this study was 3648.45 yuan per ha, 52.63\% of farm households did not receive any rent at all; this implies that the rate of land circulation without rent reached as high as $52.63 \%$. In addition, in cases where rent was paid, about $30 \%$ of farm households received between zero and 7500 yuan per ha, while $4.78 \%$ obtained more than 15,000 yuan per ha. Data show that the rates of land circulation without rent in the plain, hilly, and mountainous regions of China were about $40 \%, 57 \%$, and $57 \%$, respectively; it is therefore clear that land circulation without rent is also common nationally at present. 
Table 4 Regional differences in the cost of renting-out land

\begin{tabular}{|c|c|c|c|c|c|c|c|c|}
\hline \multirow{2}{*}{ Region } & \multicolumn{2}{|c|}{ No land rent } & \multicolumn{2}{|c|}{$\begin{array}{c}\text { Land rent } \\
(\leqslant 7500 \text { yuan } / \text { ha })\end{array}$} & \multicolumn{2}{|c|}{$\begin{array}{c}\text { Land rent }(7500- \\
15,000 \text { yuan/ha })\end{array}$} & \multicolumn{2}{|c|}{$\begin{array}{c}\text { Land rent }(\geqslant \\
15,000 \text { yuan } / \text { ha })\end{array}$} \\
\hline & $\begin{array}{l}\text { Number of } \\
\text { households }\end{array}$ & $\begin{array}{l}\text { Rate } \\
(\%)\end{array}$ & $\begin{array}{l}\text { Number of } \\
\text { households }\end{array}$ & $\begin{array}{l}\text { Rate } \\
(\%)\end{array}$ & $\begin{array}{l}\text { Number of } \\
\text { households }\end{array}$ & $\begin{array}{l}\text { Rate } \\
(\%)\end{array}$ & $\begin{array}{l}\text { Number of } \\
\text { households }\end{array}$ & $\begin{array}{l}\text { Rate } \\
(\%)\end{array}$ \\
\hline Total samples & 10,209 & 52.63 & 6440 & 33.20 & 1680 & 8.66 & 927 & 4.78 \\
\hline Plain & 2363 & 40.87 & 2257 & 39.03 & 794 & 13.73 & 368 & 6.36 \\
\hline Hilly & 4554 & 57.52 & 2929 & 36.99 & 326 & 4.12 & 108 & 1.36 \\
\hline Mountainous & 3077 & 56.96 & 1227 & 22.71 & 672 & 12.44 & 426 & 7.88 \\
\hline
\end{tabular}

The data in this table are derived from computations based on rural fixed observation point data.

The data presented in Figure 4 reveal regional differences in land rent between the main provinces of China (note that rents in this case have all been converted to the 2013 equivalent value using the discount factor). These results show that, on the whole, the amount paid by a leasee for renting-in land and the fee obtained by a landlord for renting-out are strongly consistent, although the amount in the latter case is slightly less. In terms of regional differences, data show that the land rents obtained in Jiangsu, Guangdong, Shandong, and Zhejiang provinces were consistently more than 6000 yuan per ha, about $40 \%$ higher than the national average, while in other regions such as Anhui, Hunan, Gansu, and Qinghai provinces, the rents obtained were significantly lower, less than 3000 yuan per ha. At the extreme low end of the scale, the land rents obtained in Qinghai Province were only 330 yuan per ha.

It is also worth pointing out that land rental values in Zhejiang and Yunnan provinces markedly differ from those of other regions; data show that land rent in Zhejiang Province, for example, reached as high as 11,457.3 yuan per ha, significantly more than elsewhere in China, while the equivalent figure in Yunnan Province was as high as 13,135.95 yuan per ha. These differences might be explained on the basis of our field research which shows that cultivated agriculture occurs in these two provinces, and includes crops such as bananas and loaches. In sum, the data presented in this paper reveal that land rents nationally vary between 3000 yuan per ha and 6000 yuan per ha although there are significant regional differences.

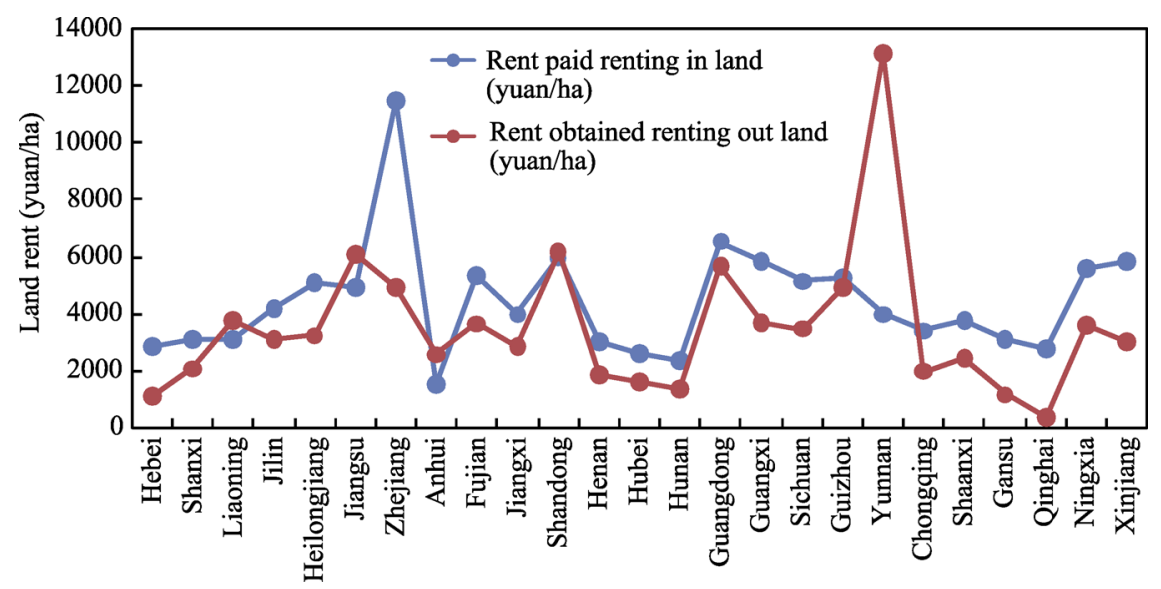

Figure 4 Regional differences in land rent across China 
Note that because the numbers of farm households involved in land circulation were less than 100 in Beijing, Tianjin, Inner Mongolia, Hainan, Shanghai, and Tibet, figures for these six regions are not reported to avoid statistical errors due to small sample sizes.

\subsection{Drivers of spatiotemporal differences in land circulation}

The data presented in this study reveal a number of typical regional heterogeneities in land circulation across China, especially between areas with different terrains; the rates of land circulation without rent in hilly and mountainous regions, for example, were about $20 \%$ higher than those seen in the plain regions. Thus, in order to accurately identify the factors driving land circulation in different regions, it was necessary to perform empirical analyses at both the national level and in terms of different terrains. Prior to further empirical analyses, however, we examined both the multicollinearity of variables and the applicability of the Heckman two-stage model. A variance inflation factor (VIF) was applied to test for multicollinearity between independent variables; these results showed that the maximum univariate VIF value for our dataset is 3.17 and that the overall VIF value is 2.16, far less than the critical value (10) and demonstrating the absence of serious collinearity between variables. Results also show that the residual of the Probit model estimate conforms to a normal distribution and that the IMR of the corresponding regression equation is significant at the $10 \%$ level; these outcomes indicate the presence of a self-selection problem in land circulation and that the Heckman two-stage model is therefore reasonable.

\subsubsection{Drivers of regional differences in land circulation at the national level}

Estimated results of the Heckman two-stage model applied in this study are presented in Table 5 and reveal the key drivers of land circulation spatiotemporal differences at the national level. It is noteworthy that variables describing the age and physical condition of the household head were not included in the second stage model because they have no significant effect on land rent and the coefficients of the others did not change significantly subsequent to their deletion. The results of this analysis show that the amount of rent obtained by a landlord is influenced by a variety of factors.

Land quality and geographic location both exert significant effects on land circulation in the first stage model; thus, in general, farm households with higher quality land tend to be more reluctant to offer it for rent. One possible explanation for this might be the fact that households can generate more income by cultivating their own land to a higher quality. Similarly, farm households in the suburbs of cities also tend to be reluctant to rent out their land because of the presence of facility and sightseeing agriculture. Our field research also shows that urban agriculture, including the farming of vegetables, fruits, and other economic crops, has flourished in most provinces across China, but especially in Beijing, Shandong, Zhejiang, and Chongqing. Although land quality and geographic location both exerted significant impacts on rent in the second stage model, the signs of these regression coefficients are opposite to those seen in the first stage model and indicate higher quality farmland with higher rents. We therefore conclude that higher quality farmland in premium locations can command higher market rents, in line with both land rent and grade-rent theories (Paul, 1957). 
Table 5 Heckman two-stage estimation results for regional differences in land circulation

\begin{tabular}{|c|c|c|c|c|}
\hline \multirow[t]{2}{*}{ Variable } & \multicolumn{2}{|c|}{$\begin{array}{l}\text { First stage model: Renting-out } \\
\text { land }=1, \text { otherwise }=0\end{array}$} & \multicolumn{2}{|c|}{$\begin{array}{l}\text { Second stage model: } \log \\
(1+\text { land rent per ha) }\end{array}$} \\
\hline & B & T-value & B & T-value \\
\hline Land quality & $-0.093^{* * *}$ & -8.92 & $0.309^{* * *}$ & 6.17 \\
\hline \multicolumn{5}{|l|}{ Geographical location } \\
\hline Suburban region & $-0.147^{* * *}$ & -10.23 & $0.392^{* * *}$ & 4.24 \\
\hline Economic level & $-0.012^{*}$ & -1.78 & $0.327^{* * *}$ & 8.03 \\
\hline \multicolumn{5}{|l|}{ Transaction costs } \\
\hline Number of land parcels & $-0.245^{* *}$ & -2.18 & $-0.029^{* * *}$ & 2.89 \\
\hline Land circulation intermediary & $0.039^{* * *}$ & 8.11 & $0.064^{* * *}$ & 7.82 \\
\hline \multicolumn{5}{|l|}{ Household characteristics } \\
\hline Rate of non-agricultural income & $0.179^{* * *}$ & 13.31 & 0.363 & 1.08 \\
\hline Age of family head & $0.139^{* * *}$ & 4.29 & - & - \\
\hline Physical condition of family head & $-0.042^{* * *}$ & -7.13 & - & - \\
\hline Number of labor force & $-0.022^{* * *}$ & -4.01 & $0.073^{* *}$ & 2.47 \\
\hline Occupation & $-0.212^{* * *}$ & -13.31 & $0.344^{* * *}$ & 3.02 \\
\hline $\log$ (total value of productive assets) & $-0.004^{* *}$ & -2.13 & $-0.005^{* * *}$ & -3.73 \\
\hline \multicolumn{5}{|l|}{ Village characteristics } \\
\hline Log(per capita income in village) & $0.101^{* * *}$ & 8.37 & $0.265^{* * *}$ & 3.29 \\
\hline Number of enterprises in village & $0.001^{* * *}$ & 3.90 & 0.003 & 1.64 \\
\hline Rate of population outflow & $0.560^{* * *}$ & 17.82 & $-0.167^{* * *}$ & -13.12 \\
\hline Financial constraints & $0.090^{* * *}$ & 5.21 & -0.060 & -0.51 \\
\hline Year dummies & \multicolumn{4}{|c|}{ Yes } \\
\hline Regional dummies & \multicolumn{4}{|c|}{ Yes } \\
\hline Lambda $(\lambda)$ & \multicolumn{4}{|c|}{$-2.87^{* * *}$} \\
\hline Wald chi-squared (32) & \multicolumn{4}{|c|}{1336.83} \\
\hline Probability greater than chi-squared & \multicolumn{4}{|c|}{0.0000} \\
\hline Number of observations & \multicolumn{4}{|c|}{130,452} \\
\hline
\end{tabular}

Abbreviations: ${ }^{* * *}, p<0.001 ;{ }^{* *}, p<0.05 ;{ }^{*}, p<0.1$. The dependent variable in the second stage model is $\log$ (1+land rent per ha) following Cheng et al. (2016); “-” denotes the variables have no significant effect on land rent; model analysis was performed using the software STATA 13.0 (Heckman, 1979).

The number of land parcels can be used as an indirect proxy for transaction cost in land circulation market. Thus, estimated results from the first stage model show that farm households are reluctant to rent out their land when transaction costs are higher, mainly the result of negotiations, contract signing, and the solving of disputes due to land fragmentation. In contrast, the second stage model shows that farm households with a higher number of land parcels tend to receive slightly lower rents. Results also show that land circulation intermediaries can act to significantly reduce transaction costs and promote the healthy development of the land rental market; these intermediaries can increase land circulation rates by $3.9 \%$ and the rents received by landlords by $6.4 \%$, respectively (Table 5 ). It is also the case that the existence of transaction costs significantly dampen the enthusiasm for land circulation among farm households; in these cases, people tend to transfer their farmland to relatives 
and acquaintances, which results in resource mismatches and a large proportion of land circulation without rent. These factors act to further reduce the potential value of land resources.

First stage model results show that the characteristics of both households and villages exert significant impacts on land circulation. Specifically, the age and condition of the household head as well as the labor force number are both negatively significant at the $1 \%$ level. In other words, families with an elderly head of household are more inclined to rent out their farmland, while people already engaged in agriculture tend to rent more land in order to expand the scale of their operation and augment their income. The nature of the land rental market therefore tends to ensure that farmland is transferred from inefficient households to those that are more effective; second stage model results also show that these characteristics tend to exert a significant influence on the rents obtained from the transferred land. Individuals who already engage in farming, for example, tend to demand higher rents, about $34.4 \%$ higher than other similar households, while higher per capita income levels and outflow proportions also tend to lead to higher rates of land circulation and thus rental levels.

\subsubsection{Drivers of land circulation in regions with different terrains}

We further attempted to identify the factors driving spatiotemporal changes in land circulation in regions characterized by different terrains, including plain, hilly, and mountainous regions. As before, prior to generating estimates from the Heckman two-stage model, it was first necessary to test multicollinearity between variables as well as the applicability of this approach. The results show that both univariate and overall VIF values in this case are much lower than 10, indicating the absence of a serious collinearity problem. At the same time the model IMR is significant at the $10 \%$ level, which indicates that both the self-selection problem in land circulation and the Heckman two-stage models are reasonable in this case. The results estimated from this approach are summarized in Table 6.

Results from the first stage model show that the effect of land quality is negatively significant at the $1 \%$ level in the plain, hilly, and mountainous regions of China; this implies that farm households with high quality land are more likely to be unwilling to rent. In contrast, results from the second stage model reveal that the coefficient of land quality in different regions is significantly different; this coefficient is positive at the $1 \%$ significance level in the plain and hilly regions, but is not significant in mountainous regions, which suggests that higher rents can be extracted from high-quality land in areas characterized by the former two terrains. Similarly, the suburban region coefficient is also significantly negative at the 5\% significance level which implies that farm households located in these regions are also not likely to rent out their land. The second stage model also shows that the suburban region coefficient is only markedly positive in hilly regions and is not significant in the other two terrain zones; this implies that farmland even in favorable locations in plain and mountainous regions do not command higher rents.

Model results show that both the number of land parcels and the presence of a land circulation intermediary exert significant impacts on both the rental of land and the size of rental incomes in different regions. Specifically, the probability of land circulation was reduced by $13.8 \%, 23.2 \%$, and $24.6 \%$ when the number of land parcels increased by one standard deviation in plain, hilly, and mountainous regions, respectively, while land rents fell by $7.3 \%$, $22.5 \%$, and $20.6 \%$. These results clearly indicate the presence of regional differences in the 
Table 6 Heckman two-stage estimation results for land circulation in regions characterized by different terrains

\begin{tabular}{|c|c|c|c|c|c|c|}
\hline \multirow[b]{2}{*}{ Variables } & \multicolumn{2}{|c|}{ Plain regions } & \multicolumn{2}{|c|}{ Hilly regions } & \multicolumn{2}{|c|}{ Mountainous regions } \\
\hline & $\begin{array}{c}\text { First stage } \\
\text { model: } \\
\text { Rent- } \\
\text { ing-out } \\
\text { land }=1 \text {, no } \\
=0\end{array}$ & $\begin{array}{l}\text { Second } \\
\text { stage } \\
\text { model: } \\
\text { Log( } 1+ \\
\text { land rent } \\
\text { per ha) }\end{array}$ & $\begin{array}{l}\text { First stage } \\
\text { model: } \\
\text { Renting-out } \\
\text { land }=1 \text {, no } \\
=0\end{array}$ & $\begin{array}{c}\text { Second } \\
\text { stage } \\
\text { model: } \\
\text { Log }(1+ \\
\text { land rent } \\
\text { per ha) }\end{array}$ & $\begin{array}{l}\text { First stage } \\
\text { model: } \\
\text { Renting-out } \\
\text { land }=1 \text {, no } \\
\quad=0\end{array}$ & $\begin{array}{c}\text { Second } \\
\text { stage } \\
\text { model: } \\
\text { Log( }(1+ \\
\text { land rent } \\
\text { per ha) }\end{array}$ \\
\hline Land quality & $-0.172^{* * *}$ & $0.324^{* * *}$ & $-0.133^{* * *}$ & $0.662^{* * *}$ & $-0.055^{* * *}$ & 0.123 \\
\hline \multicolumn{7}{|l|}{ Geographical location } \\
\hline Suburban region & $-0.304^{* * *}$ & 0.473 & $-0.053^{* *}$ & $0.510^{* * *}$ & $-0.233^{* * *}$ & -0.177 \\
\hline Economic level & $-0.060^{* * *}$ & -0.092 & -0.004 & $0.418^{* * *}$ & $0.021^{*}$ & $0.331^{* * *}$ \\
\hline \multicolumn{7}{|l|}{ Transaction costs } \\
\hline Number of land parcels & $-0.138^{* * *}$ & $-0.073^{*}$ & $-0.232^{* * *}$ & $-0.225^{* *}$ & $-0.246^{* * *}$ & $-0.206^{* *}$ \\
\hline Land circulation intermediary & $0.042^{* * *}$ & $0.051^{* *}$ & $0.027^{* * *}$ & $0.213^{* * *}$ & $0.009^{* *}$ & $0.343^{* * *}$ \\
\hline \multicolumn{7}{|l|}{ Household characteristics } \\
\hline Rate of non-agricultural income & $0.233^{* * *}$ & 0.074 & $0.155^{* * *}$ & $0.019^{* * *}$ & $0.173^{* * *}$ & -0.065 \\
\hline Age of family head & 0.009 & - & 0.086 & - & $0.372^{* * *}$ & - \\
\hline Physical condition of family head & $-0.073^{* * *}$ & - & $-0.057^{* * *}$ & - & -0.004 & - \\
\hline Number of labor force & 0.003 & $0.142^{* * *}$ & $-0.029^{* * *}$ & 0.112 & $-0.047^{* * *}$ & -0.009 \\
\hline Occupation & $-0.212^{* * *}$ & 0.193 & $-0.241^{* * *}$ & $0.911^{* * *}$ & $-0.156^{* * *}$ & 0.078 \\
\hline $\begin{array}{l}\text { Log(total value of productive } \\
\text { assets) }\end{array}$ & -0.002 & 0.015 & $0.008^{* *}$ & $-0.092^{* * *}$ & $-0.019^{* * *}$ & $-0.033^{*}$ \\
\hline \multicolumn{7}{|l|}{ Village characteristics } \\
\hline Log(per capita income in village) & $0.093^{* * *}$ & $0.294^{* * *}$ & $0.086^{* * *}$ & $-0.352^{*}$ & $0.102^{* * *}$ & $0.493^{* * *}$ \\
\hline Number of enterprises in village & $0.004^{* * *}$ & -0.006 & $-0.004^{* * *}$ & $0.017^{* * *}$ & $0.004^{* * *}$ & 0.001 \\
\hline Rate of population outflow & $0.331^{* * *}$ & -0.073 & $0.321^{* * *}$ & $-5.664^{* * *}$ & 0.058 & $-2.171^{* * *}$ \\
\hline Financial constraints & 0.013 & 0.183 & $0.183^{* * *}$ & -0.901 & 0.013 & 0.212 \\
\hline Year dummies & \multicolumn{2}{|c|}{ Yes } & \multicolumn{2}{|c|}{ Yes } & \multicolumn{2}{|c|}{ Yes } \\
\hline Regional dummies & \multicolumn{2}{|c|}{ Yes } & \multicolumn{2}{|c|}{ Yes } & \multicolumn{2}{|c|}{ Yes } \\
\hline Lambda $(\lambda)$ & \multicolumn{2}{|c|}{$-0.454^{*}$} & \multicolumn{2}{|c|}{$-6.155^{* * *}$} & \multicolumn{2}{|c|}{$-1.221^{*}$} \\
\hline Wald chi-squared (32) & \multicolumn{2}{|c|}{525.75} & \multicolumn{2}{|c|}{553.65} & \multicolumn{2}{|c|}{618.01} \\
\hline $\begin{array}{l}\text { Probability greater than } \\
\text { chi-squared }\end{array}$ & \multicolumn{2}{|c|}{0.0000} & \multicolumn{2}{|c|}{0.0000} & \multicolumn{2}{|c|}{0.0000} \\
\hline Number of observations & \multicolumn{2}{|c|}{37,338} & \multicolumn{2}{|c|}{41,322} & \multicolumn{2}{|c|}{51,792} \\
\hline
\end{tabular}

Abbreviations and notes as in Table 5 .

influence of transaction costs on land circulation; in the plain regions, for example, a reduction in transaction cost exerts little effect on land circulation, but is larger in both the hilly and mountainous regions. At the same time, the presence of circulation intermediaries also greatly enhance the probability of land rental and transfer; land rents increased by $34.3 \%$ in the presence of intermediaries if all other conditions remained the same, corresponding to a jump of $5.1 \%$ in plain regions. It is clear, therefore, that reductions in transaction costs can greatly enhance land circulation rates and thus the intrinsic value of territorial resources.

Results of the first stage model show that the age of the household head, the number in the labor, and the rate of non-agricultural income all significantly influence the probability of land circulation. These factors also vary significantly different between regions. In con- 
trast, the results of the second stage model show that occupation and non-agricultural and per capita income are the most important factors influencing land circulation and rents. It is noteworthy that the influence of these factors at this scale are similar to those seen at the national level.

In sum, higher quality farmland that is located closer to the market is likely to command a higher rent, at least based on agricultural land rent theory (Paul, 1957). The results of this study corroborate this theory in the case of plain and hilly regions while at the same time show that this is not the case in mountainous regions; higher quality farmland in these regions of China does not command higher rents. This study also shows that reductions in transaction costs exert a small influence on land circulation in the plain regions of China, but that these effects are particularly significant in hilly and mountainous regions. These results are consistent with the fact that these latter two regions have experienced significant development over the past decade (Wang et al., 2016); indeed, as a result of advancements in urbanization and the rising opportunity costs associated with farming, a large proportion of the agricultural labor force has migrated from the countryside to cities in recent years. This has gradually paralyzed village collectives and organizational structures, and has resulted in higher negotiation and contracting costs. Land fragmentation is also a very serious problem throughout China, especially in the hilly and mountainous regions, and is another important reason explaining extensive rent-free land circulation.

\section{Conclusions}

This paper outlines the results of an initial analysis of spatiotemporal changes in land circulation across China by utilizing data from 169,511 farm households collected between 2003 and 2013 by the rural fixed observation point system. A Heckman two-stage model was then developed and estimated in order to determine the key factors driving land circulation changes across China at both national and regional scales. There are four key conclusions of this research.

(1) The rate of total land circulation in China increased by $10.01 \%$ between 2003 and 2013. Specifically, the rate at which land is rented-out increased from $7.68 \%$ in 2003 to $17 \%$ in 2013, while the rate at which land is rented-in rose from only $7.41 \%$ in 2003 to just $8.1 \%$ in 2013. The rate of land circulation in the southern provinces over this period was larger than that seen in northern regions (e.g., the southern provinces of Fujian and Guangdong compared to the northern provinces of Henan and Gansu).

(2) Across China, $55.05 \%$ of farm households do not pay any rent for land they are using, while the national average rental cost is 3648.45 yuan per ha. In contrast, $52.63 \%$ of farm households do not collect any rent when leasing their lands, and the national average rental income is 4256.13 yuan per ha. In general, the rate of rent-free land circulation nationally is greater than 50\%; land rents in some provinces are up to $40 \%$ higher than the national average (e.g., Jiangsu, Zhejiang, Guangdong, and Shandong provinces), while in some provinces they are up to $20 \%$ below this benchmark (e.g., Anhui, Hunan, Hubei, and Gansu provinces).

(3) Land quality, geographic location, transaction costs, and household characteristics all exert significant impacts on land circulation, although there are significant regional differences in both the orientation and magnitude of regression coefficients. The marginal effects 
of land quality and geographic location are larger, for example, in the plain regions, while the influence of transaction costs is smaller. In contrast, in hilly and mountainous regions, the impacts of land quality and geographic location on rent incomes are very weak, while transaction costs have gradually become a key factor.

(4) The marginalization of land in hilly and mountainous regions of China underlies declines in land revenue, while high transaction costs have had an important impact on rent-free land circulation. In order to counteract these trends, it is clear that the government should strive to reduce the transaction costs associated with land circulation and establish low-cost networks and compensation systems, including circulation intermediaries, at the level of townships.

Agriculture in China has gradually become more expensive because of rapid advances in urbanization, and the rising opportunity costs of farming, as well as complex terrains and land fragmentation in the hilly and mountainous regions. As a result, land abandonment has become increasingly commonplace in the hilly and mountainous regions of China; one recent study in particular showed that the land abandonment rate has reached $21 \%$ in typical mountainous regions (Shao et al., 2016). This process will inevitably lead to falling land rents, while the extensive outflow of rural labors from these regions has gradually paralyzed village collectives and other institutions and disintegrated and scattered farm households. This has resulted in higher transaction costs and lower land rents, as well as a large proportion of rent-free land circulation.

It is clear that rent-free land circulation is a manifestation of asset depreciation in the hilly and mountainous regions of China. As urbanization has advanced, farm households who own these assets have found that they cannot support their basic living costs. Thus, both agricultural development and poverty reduction should be issues of great national concern. Although this study has identified a high proportion of rent-free land circulation, we are still unable to predict the future extent of asset depreciation in various regions. Much future research in this area is required.

\section{Acknowledgements}

We would like to acknowledge the support of the Ministry of Agriculture of China with data derived from the rural fixed observation point database.

\section{References}

Benjamin D, Brandt L, 2002. Property rights, labor markets, and efficiency in a transition economy: The case of rural China. Canadian Journal of Economics: Revue Canadienne D Economique, 35(4): 689-716.

Certo S T, Busenbark J R, Woo H et al., 2016. Sample selection bias and Heckman models in strategic management research. Strategic Management Journal, 37(13): 2639-2657.

Cheng L G, Zhang Y, Liu Z B, 2016. Does land titling promote rural land circulation in China? Management World, (1): 88-98. (in Chinese)

Deininger K, Jin S Q, 2008. Land sales and rental markets in transition: Evidence from rural Vietnam. Oxford Bulletin of Economics and Statistics, 70(1): 67-101.

Deininger K, Jin S Q, Nagarajan H K, 2008. Efficiency and equity impacts of rural land rental restrictions: Evidence from India. European Economic Review, 52(5): 892-918.

Deininger K, Savastano S, Carletto C, 2012. Land fragmentation, cropland abandonment, and land market opera- 
tion in Albania. World Development, 40(10): 2108-2122.

Du P H, Ou M H, 2008. A demonstrative study of factors influencing farmers' behavior in farmland transfer: With Jiangsu Province as an example. Scientific and Technological Management of Land and Resources, 25(1): 53-56. (in Chinese)

Heckman J, 1979. Sample specification bias as a selection error. Econometrica, 47(1): 153-162.

$\mathrm{Hu}$ W, 1997. Household land tenure reform in China: Its impact on farming land use and agro-environment. Land Use Policy, 14(3): 175-186.

Huy H T, Lyne M, Ratna N et al., 2016. Drivers of transaction costs affecting participation in the rental market for cropland in Vietnam. Australian Journal of Agricultural and Resource Economics, 60(3): 476-492.

Jin S Q, Jayne T S, 2013. Land rental markets in Kenya: Implications for efficiency, equity, household income, and poverty. Land Economics, 89(2): 246-271.

Latruffe L, Piet L, 2014. Does land fragmentation affect farm performance? A case study from Brittany, France. Agricultural Systems, 129: 68-80.

Li W H, Dai Z L, 2014. A hypothesis of farmland abandoning based on the farmers' family characters. China Population, Resources and Environment, 24(10): 143-149. (in Chinese)

Low A, 1986. Agricultural Development in Southern Africa: Farm Household Economics and the Food Crisis. London: James Currey.

Luo B L, Li S P, 2010. Transaction costs of agricultural land circulation: Based on Williamson's paradigm and evidences from Guangdong Province. Issues in Agricultural Economy, 12: 30-40. (in Chinese)

Paul F W, 1957. Theory of urban land values. Journal of Land Economics, 33(8): 228-240.

Shao J A, Zhang S C, Li X B, 2016. Effectiveness of farmland transfer in alleviating farmland abandonment in mountain regions. Journal of Geographical Sciences, 26(2): 203-218.

Sun A, Yang S, 2017. The study on urban-rural land transfer system reform in the process of new urbanization. In: Proceedings of the 20th International Symposium on Advancement of Construction Management and Real Estate. Springer: $39-49$.

Teklu T, Lemi A, 2004. Factors affecting entry and intensity in informal rental land markets in Southern Ethiopian highlands. Agricultural Economics, 30(2): 117-128.

Vranken L, Swinnen J, 2006. Land rental markets in transition: Theory and evidence from Hungary. World Development, 34(3): 481-500.

Wang G L, Liu G B, Xu M X, 2009. Above- and belowground dynamics of plant community succession following abandonment of farmland on the Loess Plateau, China. Plant and Soil, 322(1/2): 343-343.

Wang G M, Chen C, Cao G Q et al., 2017. Spatial-temporal characteristics and influential factors decomposition of farmland transfer in China. Transactions of the Chinese Society of Agricultural Engineering, 33(1): 1-7. (in Chinese)

Wang Y F, Liu Y S, Li Y H et al., 2016. The spatio-temporal patterns of urban-rural development transformation in China since 1990. Habitat International, 53(53): 178-187.

Wang Y H, Li X B, Xin L J, 2017a. The impact of agricultural labor force age on land transfer according to CHIP2013. Resources Science, 39(8): 1457-1468. (in Chinese)

Wang Y H, Li X B, Xin L J et al., 2017b. The impact of farm land management scale on agricultural labor productivity in China and its regional differentiation. Journal of Natural Resources, 32(4): 539-552. (in Chinese)

Wang Y H, Xin L J, Li X B et al., 2016. Impact of land use rights transfer on household labor productivity: A study applying propensity score matching in Chongqing, China. Sustainability, 9(1): 1-18.

Wang Y Y, Cai Y Y, Li H Y, 2015. The status of farmland transfer in the context of spatial heterogeneity and its influencing factors: Case studies in Wuhan, Jingmen and Huanggang. China Land Sciences, 29(6): 18-25. (in Chinese)

$\mathrm{Xie} \mathrm{H,} \mathrm{Lu} \mathrm{H,} \mathrm{2017.} \mathrm{Impact} \mathrm{of} \mathrm{land} \mathrm{fragmentation} \mathrm{and} \mathrm{non-agricultural} \mathrm{labor} \mathrm{supply} \mathrm{on} \mathrm{circulation} \mathrm{of} \mathrm{agricultural}$ land management rights. Land Use Policy, 68: 355-364.

Xin L J, Li X B, 2009. Changes of multiple cropping in double cropping rice area of southern China and its policy implications. Journal of Natural Resources, 24(1): 58-65. (in Chinese)

Zhang Y, Li X B, Song W, 2014. Determinants of cropland abandonment at the parcel, household and village levels in mountain areas of China: A multi-level analysis. Land Use Policy, 41: 186-192.

Zhao Y L, Li X B, 2012. Driving forces of "poplar expansion and cropland shrinkage" in the North China Plain: A case study of Wen'an County, Hebei Province. Geographical Research, 31(2): 323-333. (in Chinese) 